\title{
Foreign Exchange Exposure and Hedging of Turkish Companies: Panel Data Evidence
}

\author{
Mahmut Erdogan ${ }^{1,2}$ \\ ${ }^{1}$ Faculty of Economics and Administrative Sciences, Finance and Banking Department, Kyrgyz Turkish Manas \\ University, Bishkek, Kyrgyzstan \\ ${ }^{2}$ Faculty of Economics and Administrative Sciences, Department of Management, Gumushane University, Gumushane, \\ Turkey \\ Correspondence: Mahmut Erdogan, Faculty of Economics and Administrative Sciences, Finance and Banking \\ Department, Kyrgyz Turkish Manas University, Cengiz Aytmatov Campus, 720038, Cal, Bishkek, Kyrgyzstan Tel: \\ +996(312) 4927 65. E-mail: mahmut.erdogan@ manas.edu.kg.
}

Received: March 2, 2016

Accepted: March 16, 2016

Online Published: March 26, 2016

doi:10.5539/ibr.v9n6p44

URL: http://dx.doi.org/10.5539/ibr.v9n6p44

\begin{abstract}
This study investigates the foreign exchange exposure and determinants of risk for different time horizons of Turkish companies from 1997 to 2011. In order to analyze the effect of the 2001 crisis, the study is split into two sub-periods: pre-crisis, and post-crisis. The empirical findings of the study suggest a negative relationship between exposure and asset turnover ratio, and profit margin, while there was a positive relationship between exposure and leverage. The study also provides empirical support for the fact that the companies with a higher export rate are exposed to higher risk. Finally, large companies are subject to less risk in the short run.
\end{abstract}

Keywords: exchange rate exposure, financial crisis, horizon, Turkey

JEL: F23, F31, G32

\section{Introduction}

The collapse of the Bretton Woods System in 1973 increased the volatility in current and future cash flows of companies operating in both domestic and international markets. While the volatility in cash flows forces companies to obtain funds from capital markets, it also increases the cost of those funds. As a result, the investment level of the company declines along with its market value. Another important factor that has contributed to the volatility in cash flows of companies in recent years is the extreme competition among firms (Amiri Aghdaie et al., 2012; Riasi and Amiri Aghdaie, 2013; Riasi and Pourmiri, 2015, 2016). This competition also affects the financial markets by increasing the level of investors' and firms' uncertainty (Riasi, 2015; Ansari and Riasi, 2016).

Estimating the foreign exchange exposure companies are subject to, and defining the basics of the exchange rate volatility that will affect the value of the company, are crucial for managers who will evaluate the past actions and make decisions for the future of the company, as well as for the investors who want to ensure the optimum risk and return equilibrium in their portfolios.

The aim of this study was to investigate foreign exchange exposure and its determinants for 125 non-financial companies operating in Turkey in the 1997-2011 periods with two sub-periods before and after the 2001 financial crisis. While determining the foreign exchange exposure of Turkish manufacturers, this study also sheds light on the determinants of foreign exchange exposure. The empirical findings of the study suggest an increase in the profits of Turkish multinational and importing companies, in the post-crisis period due to the appreciation of the Turkish lira. Additionally, market risk dropped after the crisis, compared to the pre-crisis period, and increased afterwards. When the determinants of the long-run foreign exchange exposure are investigated, it is found out that asset turnover, profit margin and foreign sales to total sales have a negative and significant relationship, while leverage has positive and significant relationship with exposure. However, no statistically significant evidence was found regarding whether foreign currency derivatives and foreign assets determine exposure.

The remainder of the paper is organized as follows: the first section is a theoretical framework; the second section is a literature review; the third section presents the data and methodology; the fourth section summarizes and explains the empirical findings, and the fifth section is the conclusion. 


\section{The Theoretical Context of Foreign Exchange Exposure}

Potential reasons for foreign exchange exposure of a company are not limited to the partial use of foreign exchange in its sales or its supply of raw materials; other means of foreign exchange exposure are a company that has a subsidiary in a foreign country, and borrows from international markets with foreign exchange. Financial theory presumes that foreign exchange exposure affects the value of the company through its foreign exchange cash flows, such as export and import transactions, foreign exchange denominated debts, cash flows from subsidiaries and portfolio investment (Bartram, 2004). On the other hand, due to the unexpected fluctuations in foreign exchange, complicated risks may occur in the company's sales amounts and revenues, production costs, market share and its competitiveness. Economic theory suggests that operating cash flows of the company and discount rate which is used to determine the value of the company are affected by the unexpected fluctuations of the foreign exchange (Muller \& Verschoor, 2006).

Theoretically, foreign exchange exposure is defined as the sensitivity of the firm value to the unexpected changes in the exchange rate. Exporting companies would gain from the depreciation of the national currency while companies using imported raw materials in their production would lose. The increase in the production costs due to the rise in the exchange rate will reduce the profits and value of these firms.

Empirical literature in international financial management about the sensitivity of a firm's value to the exchange rate changes developed rapidly after the 1990s. The first studies investigating the foreign exchange exposure of companies, such as those of Jorion (1990), Bodnar \& Gentry (1993), and Bartov \& Bodnar (1994), measured the foreign exchange exposure of the companies in developed countries and defined it as the elasticity of stock returns with respect to the change in exchange rate. These studies concluded that only a few of these firms were affected by foreign exchange fluctuations. Choi \& Prasad (1995) argued that fluctuations in the exchange rate affect the value and cash flows of the firm via transactions, transitions, and economic risks. Transaction exposure is described as the effect of exchange rate on the cash flows of transactions denoted by foreign exchange, whereas transition exposure shows the effect of the exchange rate on the consolidated financial statements of a multinational company. On the other hand, economic exposure expresses the effect of exchange rates on the expected future cash flows of the company.

In order to avoid long run foreign exchange exposure resulting from parity conditions such as purchasing power parity or the International Fisher Effect (IFE), firms have started to use derivatives. Diversification of derivatives and their wide use by industrial firms reduced these firms' risks while accelerating financial innovations. However, contrary to theoretical expectations, the empirical research on the derivatives for reducing foreign exchange exposure provides contradictory results.

Yip \& Nguyen (2012) argue that only a few studies shed light on the relationship between the use of derivatives and foreign exchange exposure, and further assert that, during the global financial crisis, among the resource companies in Australia, the number of companies that used financial instruments remained unchanged, while the companies that had already been using those derivatives intensified their use of these instruments. However, they could not provide enough evidence for the increase in the use of derivatives that would reduce the foreign exchange exposure. Both Allayannis \& Ofek (2001) in their studies for American companies, and Nguyen \& Faff (2003) for Australian companies, state that firms mostly use derivatives for hedging purposes and the use of derivatives only slightly reduces foreign exchange exposure.

Recent studies, Bacha, Mohamad, Zain \& Rasid (2013), Yip \& Nguyen (2012), Du \& Hu (2012), Bartram \& Bodnar (2012), Belghitar, Clark \& Mefteh (2012), Bartram (2008), Júnior (2012), Hutson \& O'Driscoll (2010), Aggarwal \& Harper (2010), Nguyen, Faff, \& Marshall (2007), Solakoglu (2005), carried out empirical tests on the effect of changes in exchange rates on firm value and the determinants of the use of derivatives. Most of these empirical studies report only a small number of firms are significantly exposed to foreign exchange exposure and the statistical and economic effect of exchange rate changes on firm value is declared as minimal (Bartram, 2008).

\section{Literature}

Unexpected changes in the exchange rate reduce the overseas profits and the domestic currency value of a company's foreign exchange denominated assets and liabilities of the firms. In this regard, researchers attempt to estimate foreign exchange exposure and explain the determinants of foreign exchange exposure and how companies are affected by exchange rate. However, innovations in the financial markets and other instruments have equipped companies with many tools to manage their foreign exchange exposure efficiently. In fact, foreign exchange exposure is one of the most commonly hedged company risks. In addition, the popularity of foreign currency derivatives as a hedging tool makes the research on the relationship between foreign exchange exposure and the foreign currency derivatives interesting. Recent studies have specifically focused on the issue of whether the use of derivatives reduces foreign exchange exposure or not. 
One of the pioneering studies in this field by Jorion (1990) finds a positive relationship between export ratio and foreign exchange exposure. Bodnar \& Gentry (1993) point out that the industries in Canada, Japan, and the USA have a foreign exchange exposure coefficient, which is statistically between $20 \%$ and $35 \%$ significant, and the changes in exchange rates help to explain the industry profits in general. Exploring abnormal profits and the changes in exchange rates, Bartov \& Bodnar (1994) suggest that investors utilize past variations in dollars instead of its current changes in their decisions.

Chow \& Chen (1998) investigated the foreign exchange exposure of Japanese firms, and concluded that Japanese firms are usually negatively affected by it and their stock returns decline when the Japanese yen depreciates. Similarly, investigating the foreign exchange exposure of Japanese companies, $\mathrm{He} \& \mathrm{Ng}$ (1998) found that $25 \%$ of companies have a statistically significant and positive coefficient, implying an increase in the stock returns with respect to the depreciation of the Japanese yen. On the other hand, they also found a positive relationship between export ratio and the exposure.

Although real exchange rate is an indicator of rivalry environment and principal element of open economies' economic policies, emerging countries are afraid of appreciation of exchange rates. Charfi (2013) suggest that capital control relaxations and capital inflow's innovations create an exchange rate appreciation as predicted by the theory. Moreover, capital control depreciates the exchange rates and maintains competitiveness in Tunisia for 1970-2010 periods. Investigating the foreign exchange exposure of the Turkish companies, Kiymaz (2003) found that the companies with higher export and import ratios have higher foreign exchange exposure, whereas Solakoglu (2005) concludes a negative relationship between exposure and firm size and export ratio.

When used for hedging properly, derivatives could be a very effective hedging tool in company risk management and could reduce the risks for non-financial companies (Bartram et.al 2005). Companies with import and export transactions can protect their foreign exchange risk and hedge potential losses by taking appropriate positions in the same that resulting in the maximization of the shareholder value.

Allayanis \& Ofek (2001) investigated whether firms used foreign currency derivatives for hedging and speculation or not, and determined that companies using the derivatives for hedging managed to reduce their foreign exchange exposure. In addition, the decision to use derivatives was found to be related to risk factors such as foreign trade.

Nguyen \& Faff (2003) analyzed the role of derivatives in reducing the foreign exchange exposure for Australian firms found evidence that derivatives reduce short term exposure. They found a significant relationship between exposure and firm size and hedging, while their findings indicated a negative relationship between price-earnings ratio and foreign exchange exposure. Faff \& Marshall (2005) focused on giant multinational corporations (MNC) to analyze the determinants of foreign exchange exposure in the UK, USA, and Asia-Pacific regions and found only a small percentage of MNC's are open to exposure. They claim that this occurs due to the fact that US firms are hedging and balancing their international operations. Furthermore, while MNCs in the UK are affected by negative foreign exchange exposure, the MNCs in the Asia-Pacific region are open to positive exposure, and the studies that have been done on the USA cannot be generalized for the rest of the world.

Belghitar et.al (2012) investigated the effect of using foreign currency derivatives on stock prices and found that the use of derivatives have an effect on reducing foreign exchange exposure. However, they could not provide evidence to support the claim that value can be created by simply removing the risks that would cause losses. In addition, they were unable to determine any effect of derivatives on the firm value. Bartram \& Bodnar (2012) examined the relationship between foreign exchange exposure and stock returns in a comparative study and concluded that the exchange rate effect on stock returns differs significantly among countries. Specifically, they noted that $30-40 \%$ of the companies are open to exposure in emerging markets, such as Brazil, South Africa, Indonesia, Argentina, and Thailand.

Yip \& Nguyen (2012) indicated that using derivatives is the primary objective and it is lower after the crisis compared to pre-crisis periods. Nguyen et.al (2007), investigated the effect of the transition to the Euro on foreign exchange exposure of French firms and the effect of derivative usage to hedge for exposure, and determined the transition to the Euro reduced foreign exchange exposure and its magnitude. Moreover, they stated that with reduced risk, French companies used less foreign currency derivatives.

Investigating the foreign exchange exposure in Eurozone, Hutson \& O'Driscoll (2010) argued that the risks for companies outside of the Eurozone increased with the transition to the Euro, while the increase for Eurozone companies was lower. After the Euro transition was completed, however, the exposure of the Eurozone firms became much greater than that of firms outside of Eurozone. Bacha et.al (2013) investigated general and firm-specific foreign exchange exposure of 158 firms quoted in the stock exchange in Malaysia between 1990-2005 periods. Different from the developed countries findings, $71 \%$ of these companies are reported to have a statistically significant foreign exchange exposure. Furthermore, they also indicated that the companies in the sample are net importers and the US dollar is the main source of exposure. 


\section{Data and Methodology}

The current study included 22,500 observations from 125 non-financial firms quoted to the Borsa Istanbul (BIST) and monthly data for 1997-2011 periods. Companies that have financial statements and complete data for the years 1997-2011 were included. Banks and financial institutions were excluded from the analysis. The reason for this exclusion is that financial institutions are not the final beneficiary of the FX denominated derivatives and simply mediate these transactions. For exchange rate, the real effective exchange rate index was obtained from the Electronic Data Dissemination System of the Central Bank of the Republic of Turkey. An increase in the exchange rate index implied an appreciation of the Turkish lira. Market index and stock return data was obtained from the BIST database. To capture the effect of the Turkish financial crisis in 2001, the sample period was equally divided into three sub-groups: before the crisis in 1997-2001, and after the crisis in 2002-2006 and 2007-2011.

The firm specific variables that are used to determine foreign exchange exposure are asset turnover, profit margin, leverage, liquidity, size, ratio of foreign sales to total sales, and foreign currency assets to total assets. Having a high asset turnover, which is an important indicator of the operational power of firms, implies an efficient asset management, and helps the company to be resistant to the changes in price and competition conditions, thus reducing exposure. Similarly, a company with a high profit margin would be more elastic in product pricing and would handle adverse conditions better than a company with a low margin, implying a lower foreign exchange exposure. Therefore, a negative relationship is expected between exposure and asset turnover, and profit margin.

When the leverage of a firm increases, its' risk will also increase, thus the common representatives of financial distress, leverage, and foreign exchange exposure would have a positive relationship. Firms can maintain their strong liquidity positions and reduce the possibility of potential financial distress by restricting their dividend payments or by possessing more liquid assets. Therefore, a negative relationship is expected between liquidity and exposure.

Firm size is the market value of the firm's equity. Aggarwal \& Harper (2010) argue that large firms are exposed to low risk, while smaller companies have higher exposure. Thus a negative relationship is expected between firm size and foreign exchange exposure.

A firm with high exports is likely to face more uncertainties and fluctuations, thus higher exposure, which indicates a positive relationship between foreign sales to total sales and foreign exchange exposure. Similarly, higher foreign currency assets to total assets imply higher foreign exchange exposure. Companies chose to hedge against risks and reduce their exposure by using foreign currency derivatives. Consequently, foreign currency derivatives and foreign exchange exposure are expected to be negatively related.

Firstly, to determine the relationship between exchange rate changes and firm value, Equaiton 1 is estimated:

$$
\mathrm{R}_{\mathrm{it}}=\beta_{0 \mathrm{i}}+\beta_{1 \mathrm{i}} \mathrm{R}_{\mathrm{xt}}+\varepsilon_{\mathrm{it}} \quad \boldsymbol{t}=\mathbf{1} \ldots, \boldsymbol{T}
$$

Where $R_{i t}$ shows the stock return of the firm i, at time $\mathrm{t} ; R_{x t}$ is the change in the real exchange rate index and $\varepsilon_{i t}$ is the error term of the model. Following the literature, the Jorion (1991) augmented market model is specified as Equation 2:

$$
R_{i t}=\beta_{0 i}+\beta_{1 i} R_{x t}+\beta_{2 i} R_{m t}+\varepsilon_{i t}
$$

Where, $R_{m t}$ represents the return of market index and the other variables are the same. $\beta_{2 i}$ in Equaiton 2 shows the foreign exchange exposure increasing due to market risk. This two-factor model is used in studies investigating exposure, such as those of Bodnar \& Gentry (1993), Bartov \& Bodnar (1994), and Griffin \& Stulz (2001).

Next, by following Hutson \& O’Driscoll (2010), Aggarwal \& Harper (2010) and Nguyen et.al (2007), the $\beta_{1 i}$ obtained from the second equation are used to measure the foreign exchange exposure as in Equation 3:

$$
\phi_{\mathrm{i}}=\sqrt{\left|\beta_{1 \mathrm{i}}\right|}
$$

Where, $\phi_{\mathrm{i}}$ is the foreign exchange exposure obtained from $\beta_{1 \mathrm{i}}$ in Equation 2. Employing only the absolute value of $\beta_{1 \mathrm{i}}$ would cause a truncation bias, and would therefore lead to a nonnormal error term. For this reason, the square root was used. In the second stage, a cross section regression is used to estimate the determinants of foreign exchange exposure in the long run. The cross section regression is specified as follows:

$$
\phi_{\mathrm{i}}=\lambda_{0}+\lambda_{1} \text { AT }+\lambda_{2} \text { PrMar }+\lambda_{3} \text { Lev }+\lambda_{4} \text { Liq }+\lambda_{5} \text { Size }+\lambda_{6} \text { FSTS }+\lambda_{7} \text { FCTA }+\lambda_{8} \text { DERIV }+\varepsilon_{i}
$$

Where AT is average asset turnover, PrMar is the average gross profit margin, Lev is the average ratio of total debt to total assets, Liq is the quick ratio. Size is the natural logarithm of the market value, FSTS is the average foreign sales to total sales ratio, FCTA is the ratio of foreign currency assets to total assets. DERIV is a dummy variable equaling unity if a firm uses foreign currency derivatives and zero otherwise. $\mathrm{T}$ 
Table 1. Descriptive statistics

\begin{tabular}{llllllll}
\hline Variable & FX Change & Market & Return & & & \\
\hline Mean & 0.003 & 0.032 & 0.039 & & & \\
Standard Deviation & 0.035 & 0.149 & 0.218 & & & \\
Min & -0.147 & -0.39 & -0.75 & $N_{\% 10}^{+}$ & $N_{\% 10}^{-}$ & $N$ \\
Max & 0.145 & 0.798 & 8.866 & & & \\
Obs & 22500 & 22500 & 22500 & $36 / 107$ & $1 / 18$ & 125 \\
\hline
\end{tabular}

Descriptive statistics for the change in the exchange rate, the BIST index and the stock returns are presented in Table 1. During 1997-2011, while all the stocks in BIST yielded, on average, a 4\% return per annum, the BIST-100 index yielded a 3\% return. On the other hand, the real effective exchange rate index increased. 03\% annually, indicating a depreciation of the Turkish lira against the currencies in the exchange rate basket. Twenty-nine percent of the companies in the sample were exposed to positive foreign exchange risk. This ratio is close to the findings of $\mathrm{He} \& \mathrm{Ng}(1998)$ and Bodnar \& Gentry (1993).

\section{Empirical Results}

\subsection{Foreign Exchange Exposure of Turkish Firms}

Before estimating the models in Equations 1 and 2 above, in order to analyze whether panel data has a unit root, first and second generation unit root tests were applied and results are presented in Table 2.

According to the test Levin, Lin, \& Chu, variables return, FX change and the market series have a unit root which means they are stationary. The series are also stationary according to Breitung, Harris, and Tzavalis. In the test of Im, Pesaran, \& Shin that allows an autocorrelation coefficient for each unit, all three series are stationary. All three variables are also stationary according to the Fisher's augmented Dickey-Fuller (ADF) test.

All variables are stationary according to Hadri unit root test. The return series is stationary according to the probability values of Pesaran CADF $\mathrm{Z}(\bar{t})$ statistics. However, FX change and market series are not stationary according to probability values of Pesaran CADF Z $(\bar{t})$ statistics while they are stationary according to $\bar{t}$ statistics.

Table 2. Results of Panel Unit Root Tests

\begin{tabular}{lllll}
\hline & \multicolumn{3}{l}{ Return } & \multicolumn{3}{l}{ FX Change } \\
\cline { 2 - 5 } Levin,Lin\&Chu & t statistics I $(0)$ & Probability I(0) & t statistics I $(0)$ & Probability I(0) \\
\cline { 2 - 5 } Breitung & -150 & $0.000^{*}$ & -95.963 & $0.000^{*}$ \\
Harris-Tzavalis & -36.258 & $0.000^{*}$ & -85.798 & $0.000^{*}$ \\
Im,Pesaran\&Shin & 0.0333 & $0.000^{*}$ & 0.328 & $0.000^{*}$ \\
Fisher ADF-Chi-square & -150 & $0.000^{*}$ & -99.859 & $0.000^{*}$ \\
Hadri-Ztest & -4.865 & $0.000^{*}$ & 8846.601 & $0.000^{*}$ \\
Pesaran CADF & -44.299 & $1.000^{*}$ & -8.018 & $1.000^{*}$ \\
& Market & & 54.659 & 1.000 \\
Levin,Lin\&Chu & t statistics I(0) & Probability I(0) & & \\
\cline { 2 - 5 } Breitung & -160 & $0.000^{*}$ & & \\
Harris-Tzavalis & -2.064 & $0.000^{*}$ & & \\
Im,Pesaran\&Shin & -0.005 & $0.000^{*}$ & & \\
Fisher ADF-Chi-square & -160 & $0.000^{*}$ & & \\
Hadri-Ztest & 9010.913 & $0.000^{*}$ & & \\
Pesaran CADF & -6.644 & $1.000^{*}$ & & \\
\hline
\end{tabular}

Empirical results of this study are presented in Table 3. In the first two columns are the Random Effect results covering all periods of the study (from 1997 to 2011). The model result from the first equation is presented in the first column. The change in exchange rates is positive and statistically significant at a $1 \%$ level. A positive $\beta_{1 i}$ value indicates that changes in exchange rate increase the firm's value. However, the two-factor model in the second column shows that when market risk is added to the model, the effect of the changes in exchange rate on the firm value decreased.

The second part (III and IV) shows the estimates for the pre-crisis period. Compared to all periods, in the pre-crisis period, the change in exchange rates had the lowest potential to increase firm value. Furthermore, when market index is added to the model, the effect of exchange rate fluctuations in firm value decreased but no statistically significant result was found. The post-crisis period was divided into two sub-periods due to the global crisis that emerged 2007. When the first post-crisis period (V and VI) is, compared to the pre-crisis period, the exchange rate fluctuations increase firm value by approximately two times. The other model that includes market return also supports this situation. Surprisingly, in second post-crisis period (VII and VIII), the changes in exchange rate triple the firm value. 
Table 3. Foreign Exchange Exposure and Market Risks of Turkish Companies

\begin{tabular}{|c|c|c|c|c|c|c|c|c|}
\hline & \multicolumn{2}{|c|}{ 1997-2011 Full Term } & \multicolumn{2}{|c|}{ 1997-2001 Pre-Crises } & \multicolumn{2}{|c|}{ 2002-2006 Post-Crises } & \multicolumn{2}{|c|}{ 2007-2011 Post-Crises(2) } \\
\hline & I & II & III & IV & V & VI & VII & VIII \\
\hline \multirow{2}{*}{$\overline{\beta_{1 i}}$} & $0.447 * * *$ & $0.064 *$ & $0.162 * *$ & 0.058 & $0.312 * * *$ & $0.104^{* *}$ & $1.371 * * *$ & $0.287 * * *$ \\
\hline & $(0.042)$ & $(0.036)$ & $(0.083)$ & $(0.064)$ & $(0.050)$ & $(0.045)$ & $(0.089)$ & $(0.092)$ \\
\hline \multirow[t]{2}{*}{$\beta_{2 i}$} & & $0.784 * * *$ & & $0.796^{* * *}$ & & $0.723 * * *$ & & $0.778 * * *$ \\
\hline & & $(0.008)$ & & $(0.011)$ & & $(0.017)$ & & $(0.026)$ \\
\hline \multirow[t]{2}{*}{ Constant } & $0.038 * * *$ & $0.013 * * *$ & $0.065 * * *$ & $0.014 * * *$ & $0.027 * * *$ & $0.011 * * *$ & $0.021 * * *$ & $0.015^{* * * *}$ \\
\hline & $(0.002)$ & $(0.001)$ & $(0.003)$ & $(0.003)$ & $(0.002)$ & $(0.002)$ & $(0.002)$ & $(0.002)$ \\
\hline Observations & 22,500 & 22,500 & 7,500 & 7,500 & 7,500 & 7,500 & 7,500 & 7,500 \\
\hline Number of id & 125 & 125 & 125 & 125 & 125 & 125 & 125 & 125 \\
\hline $\mathrm{R}^{2}$ & 0.005 & 0.29 & 0.0005 & 0.399 & 0.0051 & 0.204 & 0.03 & 0.135 \\
\hline Wald chi ${ }^{2}$ & 113.25 & 9052.51 & 3.87 & 4982.34 & 38.20 & 1922.25 & 236.16 & 1171.76 \\
\hline
\end{tabular}

Notes: $\beta_{1 i}$ presents the coefficient of change in the real exchange rate index and $\beta_{2 i}$ demonstrates the return of market index. Standard errors are shown in parentheses. $* * *, * *$, and $*$ represent significance at $1 \%, 5 \%$, and $10 \%$ levels, respectively.

The fundamental reason behind this is that because of the appreciation Turkish lira, imports increase and there is a positive exposure that also shows that the companies are net importers. According to TurkStat's foreign trade statistics, Turkish imports has increased 5 times from 1997 to 2011, and reached to 240 billion dollars (www.turkstat.gov.tr).

Contrary to the findings of Kiymaz (2003), Solakoglu (2005) and Bacha et.al (2013), a positive beta coefficient indicates that the companies in the current sample are mostly net importers. This demonstrates that Turkish firms import raw materials and semi-manufactured goods when the Turkish lira appreciates, and increase their profitability as indicated by Nguyen \& Faff (2005). On the other hand, market exposure decreased in the post-crisis period compared to the pre-crisis period and increased in the second five years in the post-crisis period.

\subsection{The Determinants of Exchange Rate Exposure}

The effect of foreign exchange exposure on non-financial firm stock price is dependent on the firm's characteristics such as international activities including imports and exports, firm size, the company's financing policies such as borrowing with foreign exchange, hedging with foreign currency derivatives, and firm liquidity (Bartram 2008, Rossi Junior 2012). Determining the exchange rate risk in the short run could be difficult because of the firm's hedging behaviors. On the other hand, when experiencing economic exposure, hedging is very difficult and can be observed over the long-run, and thus firms are more open to exchange rate exposure. If the effects of exchange rate fluctuations are longer and more permanent, longer periods are more appropriate for forecasts. Since using long term returns is more beneficial for measuring economic exposure, this study focused on firms' long term risks and analyzed the determinants of foreign exchange exposure.

In Table 4, a summary statistics of the firm's financial variables is given in Panel A, while Panel B shows the correlation coefficients of the variables. The average asset turnover ratio for the firms in the sample is 1.068 and the firm with the highest asset turnover has the three times of this ratio. Firms in the sample are generally large firms, their average export ratio is $25 \%$, and the highest export ratio in the sample is $81 \%$. They are categorized as firms with international activities since their export ratio is greater than $10 \%$. According to Panel $\mathrm{B}$, there is no relation between the variables that can cause multicollinearity.

Table 5 shows the determinants of foreign exchange exposure and time horizon results from 3 to 12 months for Equation 4. When time preference moves from the shortest term to the longest term, explanatory power increases with an increase of $\mathrm{R}^{2}$ from $7 \%$ to $12 \%$. In the three month period, only one factor met expectations, and was negative and statistically significant at a 5\% level. This reveals that big companies are subject to less risk and small firms experience more risk. This can be explained in two ways. Firstly, because of the economies of scale in hedging, big firms are able to better protect themselves against exposure. Secondly, big firms are more likely to be multinational, and companies operating in multiple countries are subject to lower exposure. This empirical finding is consistent with the results of Nguyen \& Faff (2003), Hutson \& O'Driscoll (2010) and Aggarwall \& Harper (2010). The FSTS variable that shows the export ratio in 9 months preference is positive and statistically significant, which shows that the firms with higher export ratios are subject to less risk. 
Table 4. Summary statistics of companies' financial characteristics

\begin{tabular}{|c|c|c|c|c|c|c|c|}
\hline \multicolumn{8}{|c|}{ Panel A: Summary statistics of financial characteristics } \\
\hline Variable & \multicolumn{2}{|l|}{ Obs } & Mean & Std. Dev. & \multicolumn{2}{|c|}{ Min } & Max \\
\hline$A T$ & \multicolumn{2}{|l|}{125} & 1.068 & 0.521 & \multicolumn{2}{|c|}{0.113} & 3.786 \\
\hline PrMar & \multicolumn{2}{|l|}{125} & 0.243 & 0.106 & \multicolumn{2}{|c|}{-0.023} & 0.669 \\
\hline Lev & \multicolumn{2}{|l|}{125} & 0.537 & 0.365 & \multicolumn{2}{|c|}{0.147} & 3.275 \\
\hline Liq & \multicolumn{2}{|l|}{125} & 0.524 & 0.788 & \multicolumn{2}{|c|}{0.007} & 5.023 \\
\hline Size & \multicolumn{2}{|l|}{125} & 18.398 & 1.490 & \multicolumn{2}{|c|}{15.706} & 22.162 \\
\hline FSTS & \multicolumn{2}{|l|}{125} & 0.250 & 0.201 & \multicolumn{2}{|l|}{0} & 0.811 \\
\hline FCTA & \multicolumn{2}{|l|}{125} & -0.038 & 0.096 & \multicolumn{2}{|c|}{-0.819} & 0.189 \\
\hline \multicolumn{8}{|c|}{ Panel B: Correlation coefficients of financial variables } \\
\hline & AT & PrMar & Lev & Liq & Size & FSTS & FCTA \\
\hline AT & 1 & & & & & & \\
\hline PrMar & -0.311 & 1 & & & & & \\
\hline Lev & 0.099 & -0.143 & 1 & & & & \\
\hline Liq & -0.117 & 0.179 & -0.382 & 1 & & & \\
\hline Size & 0.212 & 0.120 & -0.277 & 0.153 & 1 & & \\
\hline FSTS & 0.012 & -0.193 & 0.076 & -0.101 & -0.029 & 1 & \\
\hline FCTA & 0.016 & 0.126 & -0.728 & 0.368 & 0.209 & -0.040 & 1 \\
\hline
\end{tabular}

This is also consistent with Chow \& Chen's (1998) findings. Asset turnover is positive and statistically significant; however, its sign is contrary to expectations. In the 12 month time preference, asset turnover and profit margin variables are negative and statistically significant at $10 \%$ and 5\% levels, respectively. Signs of the variables are positive with expectations and are also proof that firms with high asset turnover and profit margins are less prone to foreign exchange exposure. Furthermore, firms that have a high level of debt, financial risk, and leverage are more sensitive to additional levels of risk.

The Lev variable is positive and statistically significant. In the long run time horizon, the FSTS variable is surprisingly negative. This negative coefficient means that while Turkish lira depreciates, firm stock returns decrease. As discussed by Solakoglu (2010) it can be argued that due to an increase in the foreign exchange exposure, Turkish exporter firms are impacted negatively by parity risk in the long horizon. The DERIV variable, showing the use of derivatives, which means that firms using foreign currency derivatives decrease their foreign exchange exposures, has a sign in line with expectations but is not statistically significant. The other variables were not statistically significant either.

Table 5. Cross section regression analysis of long horizon determinants of foreign exchange exposure

\begin{tabular}{lccccc}
\hline Expected sign & & 3 months & 6 months & 9 months & 12 months \\
\hline AT & - & -0.098 & -0.174 & $\mathbf{1 . 3 7 9 *}$ & $\mathbf{- 0 . 2 2 3}$ \\
& & 0.225 & 0.157 & $\mathbf{0 . 7 0 9}$ & $\mathbf{0 . 1 1 3}$ \\
PrMar & - & 0.022 & -0.103 & 0.517 & $\mathbf{- 1 . 2 6 5 * *}$ \\
& & 0.065 & 0.214 & 1.282 & $\mathbf{0 . 5 3 1}$ \\
Lev & + & -0.07 & 0.204 & -0.308 & $\mathbf{0 . 6 0 0 * *}$ \\
& & 0.183 & 0.228 & 1.222 & $\mathbf{0 . 2 6 6}$ \\
Liq & - & 0.041 & -0.014 & 0.029 & -0.042 \\
& & 0.055 & 0.074 & 0.323 & 0.072 \\
Size & - & $\mathbf{- 0 . 0 5 7 * *}$ & -0.041 & 0.013 & 0.006 \\
& & $\mathbf{0 . 0 2 4}$ & 0.032 & 0.179 & 0.039 \\
FSTS & + & 0.072 & 0.258 & $\mathbf{2 . 6 1 2} * *$ & $\mathbf{- 0 . 4 4 1 *}$ \\
& & 0.153 & 0.195 & $\mathbf{1 . 1 9 3}$ & $\mathbf{0 . 2 5 9}$ \\
FCTA & + & -0.191 & 0.712 & -1.531 & 1.413 \\
& & 0.529 & 0.704 & 3.838 & 0.981 \\
DERIV & - & 0.088 & 0.047 & -0.568 & -0.071 \\
& & 0.085 & 0.106 & 0.594 & 0.153 \\
\hline Constant & & $\mathbf{1 . 7 1 2 * * *}$ & $1.509 * *$ & -0.657 & $\mathbf{1 . 6 9 3} * *$ \\
& & $\mathbf{0 . 4 5 3}$ & $\mathbf{0 . 5 9 2}$ & 3.352 & $\mathbf{0 . 7 3 8}$ \\
Observations & & 125 & 125 & 125 & 125 \\
R-squared & & 0.067 & 0.065 & 0.074 & 0.123 \\
\hline
\end{tabular}




\section{Conclusion}

The aim of this study was to determine Turkish non-financial firms' foreign exchange exposure between 1997-2001, to analyze the change in exposure before and after the financial crisis in 2001, and to examine firm characteristics regarding foreign exchange exposure in different time horizons. The main contribution of this study is that it is the first study analyzing the determinants of exposure in both the short-term and long-term for Turkish non-financial firms. The study included 125 firms with 22,500 observations.

Empirical findings show that Turkish firms have experienced positive foreign exchange exposure before and after the crisis (except the fourth model). Nguyen \& Faff (2005) suggest that since industrial firms import semi-manufactured goods and raw materials with foreign exchange, their costs are dependent on exchange rates and thus have a net positive exposure and when domestic currency appreciates, these firms will gain profits. Empirical findings of this study are similar to the views of Nguyen \& Faff (2005) in that the firm value increases with increases in real effective exchange rates.

The long run cross-section results of the foreign exchange exposure are statistically significant and have a negative relationship with asset turnover and profit margin. Similarly, the FSTS variable is also negatively correlated. In line with the expectations, leverage variable and foreign exchange exposure are positively related. While financial risk of the firms' increases, so does their foreign exchange exposure. In short horizons, there is a negative relation between firm size and foreign exchange exposure. Large firms experience low exposure in the short run, while small firms experience higher exposure.

\section{References}

Aggarwal, R., \& Harper, J. T. (2010). Foreign exchange exposure of domestic corporations. Journal of International Money and Finance, 29(8), 1619-1636. http://dx.doi.org/10.1016/j.jimonfin.2010.05.003

Allayannis, G., \& Ofek, E. (2001). Exchange rate exposure, hedging and the use of foreign currency derivatives. Journal of International Money and Finance, 20, 273-296. http://dx.doi.org/10.1016/S0261-5606(00)00050-4

Amiri, A. S. F., Seidi, M., \& Riasi, A. (2012). Identifying the Barriers to Iran's Saffron Export by Using Porter's Diamond Model. International Journal of Marketing Studies, 4(5), 129-138. http://dx.doi.org/10.5539/ijms.v4n5p129

Ansari, A., \& Riasi, A. (2016). An Investigation of Factors Affecting Brand Advertising Success and Effectiveness. International Business Research, 9(4), 20-30. http://dx.doi.org/10.5539/ibr.v9n4p20

Bacha, O. I., Mohamad, A., Zain, S., \& Rasid, M. (2013). Foreign exchange exposure and impact of policy switch- the case of Malaysian listed firms. Applied Economics, 45, 2974-2984. http://dx.doi.org/10.1080/00036846.2012.684790

Bartov, E., \& Bodnar, G. M. (1994). Firm valuation, earnings expectations, and the exchange rate exposure effect. Journal of Finance, 49, 1755-1785. http://dx.doi.org/10.1111/j.1540-6261.1994.tb04780.x

Bartram, S. M. (2004). Linear and nonlinear foreign exchange rate exposure of German nonfinancial corporations. Journal of International Money and Finance, 23, 673-699. http://dx.doi.org/10.1016/j.jimonfin.2004.03.002

Bartram, S. M. (2008). What lies beneath: Foreign exchange rate exposure, hedging and cash flows. Journal of Banking and Finance, 32(8), 1508-1521. http://dx.doi.org/10.1016/j.jbankfin.2007.07.013

Bartram, S. M., Dufey, G., \& Frenkel, M. R. (2005). A primer on the exposure of nonfinancial corporations to foreign exchange rate risk. Journal of Multinational Financial Management, 15(4/5), 394-413. http://dx.doi.org/10.1016/j.mulfin.2005.04.001

Bartram, S. M., \& Bodnar, G. M. (2012). Crossing the lines: The conditional relation between exchange rate exposure and stock returns in emerging and developed markets. Journal of International Money and Finance, 31, 766-792. http://dx.doi.org/10.1016/j.jimonfin.2012.01.011

Belghitar, Y., Clark E., \& Mefteh S. (2013). Foreign currency derivative use and shareholder value. International Review of Financial Analysis, 29, 283-293. http://dx.doi.org/10.1016/j.irfa.2012.02.004

Bodnar, G. M., \& Gentry, W. M. (1993). Exchange rate exposure and industry characteristics: evidence from Canada, Japan and the USA. Journal of International Money and Finance, 12, 29-45. http://dx.doi.org/10.1016/0261-5606(93)90008-Y

Choi, J. J., \& Prasad, A. M. (1995). Exchange risk sensitivity and its determinants: a firm and industry analysis of US multinationals. Financial Management, 24, 77-88. http://dx.doi.org/10.2307/3665559

Chow, E. H., \& Chen, H. L. (1998). The determinants of foreign exchange rate exposure: evidence on Japanese firms. 
Pacific-Basin Finance Journal, 6, 153-174. http://dx.doi.org/10.1016/S0927-538X(97)00020-6

Du, D., \& Hu, O. (2012). Exchange rate risk in the US stock market. Journal of International Financial Markets, Institutions and Money, 22, 137-150. http://dx.doi.org/10.1016/j.intfin.2011.08.003

Faff, R., \& Marshall, A. (2005). International Evidence on the Determinants of Foreign Exchange Rate Exposure of Multinational Corporations. Journal of International Business Studies, 36(5), 539-558. http://dx.doi.org/10.1057/palgrave.jibs.8400155

Foreign Trade by Years. (2012). Turkish Statistical Institute. http://www.turkstat.gov.tr/ UstMenu.do?metod=temelist (accessed May, 3 2012).

Griffin, J. M., \& Stulz, R. M. (2001). International competition and exchange rate shocks: a cross-country industry analysis of stock returns. Review of Financial Studies, 14, 215-241. http://dx.doi.org/10.1093/rfs/14.1.215

He, J., \& Ng, L. K. (1998). The foreign exchange exposure of Japanese multinational corporations. Journal of Finance, 53, 733-753. http://dx.doi.org/10.1111/0022-1082.295575

Hutson, E., \& O'Driscoll, A. (2010). Firm-level exchange rate exposure in the Eurozone. International Business Review, 19(5), 468-471. http://dx.doi.org/10.1016/j.ibusrev.2009.02.007

Jorion, P. (1990). The exchange rate exposure of US multinationals. Journal of Business, 63, 331-345. http://dx.doi.org/10.1086/296510

Kiymaz, H. (2003). Estimation of foreign exchange exposure: an emerging market application. Journal of Multinational Financial Management, 13, 71-84. http://dx.doi.org/10.1016/S1042-444X(02)00034-8

Muller, A., \& Verschoor, W. F. C. (2006). Foreign exchange risk exposure: survey and suggestions. Journal of Multinational Financial Management, 16, 385-410. http://dx.doi.org/10.1016/j.mulfin.2005.09.001

Nguyen, H., Faff, R., \& Marshall A. (2007). Exchange rate exposure, foreign currency derivatives and the introduction of the Euro: French evidence. International Review of Economics and Finance, 16, 563-577. http://dx.doi.org/10.1016/j.iref.2006.01.002

Nguyen, H., \& Faff, R. (2003). Can the use of foreign currency derivatives explain variations in foreign exchange exposure? Evidence from Australian companies. Journal of Multinational Financial Management, 13, 193-215. http://dx.doi.org/10.1016/S1042-444X(02)00051-8

Riasi, A., \& Amiri Aghdaie, S. F. (2013). Effects of a Hypothetical Iranian Accession to the World Trade Organization on Iran's Flower Industry. Consilience: The Journal of Sustainable Development, 10(1), 99-110. http://dx.doi.org/10.7916/D8HQ3ZK8

Riasi, A. (2015). Competitive Advantages of Shadow Banking Industry: An Analysis Using Porter Diamond Model. Business Management and Strategy, 6(2), 15-27. http://dx.doi.org/10.5296/bms.v6i2.8334

Riasi, A., \& Pourmiri, S. (2015). Effects of online marketing on Iranian ecotourism industry: Economic, sociological, and cultural aspects. Management Science Letters, 5(10), 915-926.http://dx.doi.org/10.5267/j.msl.2015.8.005

Riasi, A., \& Pourmiri, S. (2016). Examples of Unsustainable Tourism in Middle East.Environmental Management and Sustainable Development, 5(1), 69-85. http://dx.doi.org/10.5296/emsd.v5i1.8705

Rossi Júnior, J. L. (2012). Understanding Brazilian companies' foreign exchange exposure. Emerging Markets Review, 13, 352-365. http://dx.doi.org/10.1016/j.ememar.2012.03.007

Solakoglu, M. N. (2005). Exchange Rate Exposure and Firm-Specific Factors: Evidence from Turkey. Journal of Economic and Social Research, 7(2), 35-46.

Solakoğlu, M. N. (2010). Exchange rate exposure and real exports. Applied Economics Letters, 17, 457-462. http://dx.doi.org/10.1080/13504850801935331

Yip, W. H., \& Nguyen, H. (2012). Exchange rate exposure and the use of foreign currency derivatives in the Australian resources sector. Journal of Multinational Financial Management, 22, 151-167. http://dx.doi.org/10.1016/j.mulfin.2012.06.003

\section{Copyrights}

Copyright for this article is retained by the author(s), with first publication rights granted to the journal.

This is an open-access article distributed under the terms and conditions of the Creative Commons Attribution license (http://creativecommons.org/licenses/by/3.0/). 